\title{
Quantifying the Relationships of Impact Factors on Non-Point Source Pollution Using the Boosted Regression Tree Algorithm
}

\author{
Wei Zhang ${ }^{1}$, Feng-Yun Sun², Miao Liü ${ }^{3 *}$, Chun-Lin Li ${ }^{3}$ \\ ${ }^{1}$ College of Land and Environment, Shenyang Agricultural University, Shenyang 110866, China \\ ${ }^{2}$ School of Geographic Sciences, East China Normal University, Shanghai 200241, China \\ ${ }^{3}$ Institute of Applied Ecology, Chinese Academy of Sciences, Shenyang 110164, China
}

Received: 9 May 2016

Accepted: 26 July 2016

\begin{abstract}
Non-point source (NPS) pollution contributes greatly to the contamination of surface water quality and has aroused widespread concerns. NPS pollution is influenced by a multitude of site-related factors whose effects are complicated. We estimated NPS pollution with a soil and water assessment tool (SWAT) model in China's Fan River watershed. A new method, boosted regression tree (BRT), was proposed to study the relationship of impact factors on NPS pollution. We analyzed the effects of elevation, land use, soil, and slope on the patterns of sediment transport, total nitrogen (TN), and total phosphorus (TP). The results showed that $\mathrm{R}^{2}$ values were higher than 0.76 , and NSE was higher than 0.67 . The SWAT model can estimate NPS pollution effectively in a study area. Although the spatial pattern of sediment and TP was quite consistent, the relationship between sediment and TN was weak. The contribution of impact factors for sediment TN and TP were different. Slope is the most important impact factor for sediment and TP load. Land use is the most important impact factor for TN load. The BRT model can reduce barriers to factor complexity and promote understanding of the NPS pollution formation mechanism. We proposed control strategies of pollution sources, and our research has proven to be useful for the explanation of impact factors in NPS pollution study, which is meaningful for NPS pollution control.
\end{abstract}

Keywords: non-point source pollution, boosted regression tree, SWAT model, impact factors

\section{Introduction}

Water quality is becoming an increasing concern. The experience of the last decades has shown that controlling point sources only failed to achieve acceptable basin-wide water quality. NPS pollution is increasingly

*e-mail: lium@iae.ac.cn

responsible for bad water quality [1-4]. Environmental factors have a substantial effect on the formation of NPS pollution, the relationship between environmental factors and water quality provides important theoretical and practical significance for effectively addressing NPS pollution management problems and the optimization of water quality. However, the relationship between water quality and environmental controls is complex and areaspecific [5-6]. Improvement of our understanding of the 
quantitative relationship between sediment, NPS pollution loads, and their origins at the watershed scale is frequently restricted by lack of both data and applicable techniques [7-8].

Models are powerful tools for simulating the effect of watershed processes and management on soil and water resources [9]. Computer-based watershed models are efficient and cost-effective because of their ability to perform long-term simulation of the effects of watershed processes and management activities on water quantity and water quality [10]. SWAT is one of the most commonly used and well supported water quality modeling systems available [11-13]. The strengths of SWAT are that it is computationally efficient and uses readily available input data and its process based on nutrient biogeochemistry sub-models [14-16].

NPS pollution research has been a hot topic in recent years, with most of the studies mainly focusing on three aspects: 1) modelling the quantity and spatial variability of NPS pollution [17-19], 2) evaluating the efficiency of NPS pollution management [20-21], 3) and improving method performance of modelling/assessing [22-23]. However, there is a paucity of research that discussed the quantification relationship between environmental factors and NPS pollution despite the importance in addressing the problem.

The nonlinearities and interactions in NPS pollution need techniques that are flexible enough to express typical features of the data for both explanation and prediction. The BRT algorithm can be summarized in ways that give powerful ecological insight to the relationship [24]. Four obvious advantages that make the BRT model differ fundamentally from traditional regression methods are:
1. Simplified preparation of candidate predictors because predictor variables can be of any type (numeric, binary, categorical, etc.), and there is no need for prior data transformation [25].

2. Insensitive to outliers, BRT can accommodate missing data in predictor variables by using surrogates [26].

3. The ability to fit a large number of weak relationships in a predictive model and automatically handle interaction effects between predictors [27].

4. The information is represented in a powerful ecological way that is intuitive and easy to visualize.

Given the source-complicated nature of the formation mechanism and the large number of weak and contingent relationships between NPS pollution and influencing factors, BRT would seem to be an ideal tool for NPS pollution characterization.

The objectives of this research are to determine: 1) if it is possible to obtain NPS pollution data and their related environmental characteristics that can fit the reality spatially and temporally effective and 2) if the BRT is strong enough to explain the relationship between pollution data and their influencing factors.

\section{Materials and Methods}

\section{Study Area}

The Fan River watershed was chosen as the study case, the area is $1,037.66 \mathrm{~km}^{2}\left(123.62-124.55^{\circ} \mathrm{E}, 42.00-42.30^{\circ} \mathrm{N}\right.$; Fig. 1) within the Liao River basin in northeastern China. The Fan, which is $118 \mathrm{~km}$ long, is a typical semi-arid and semi-humid seasonal river, with annual precipitation over

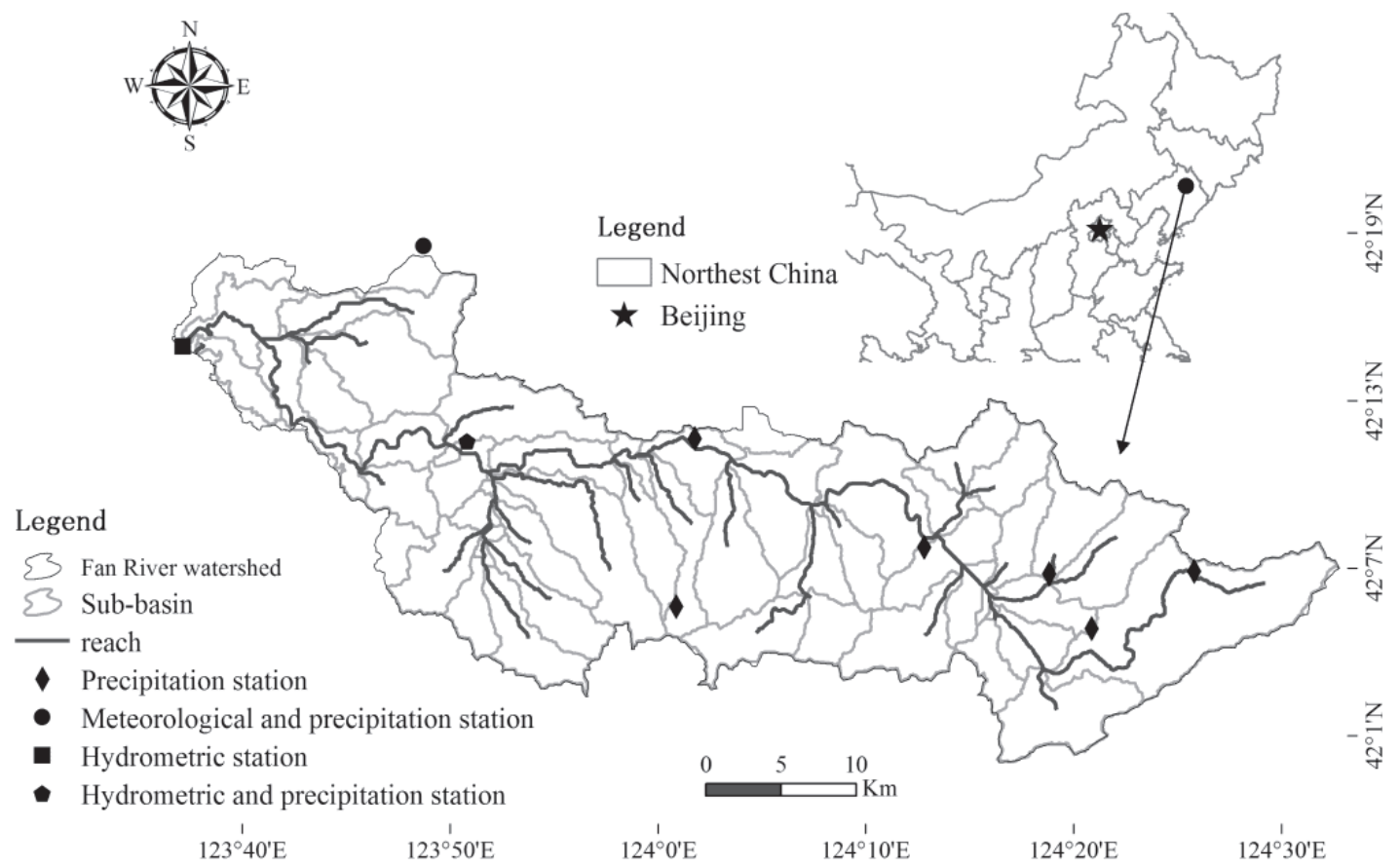

Fig. 1. Map of the Fan River watershed. 
the 2003-12 study period ranging from 480 to $1,036 \mathrm{~mm}$ (mainly concentrated in 4-9 months). The primary land use categories include forestland (57\%), farmland (33\%), and settlement area (7\%) in 2013. The population is about 22,000 people. This watershed was selected due to its lack of large-scale sewage treatment facilities and the fact that NPS pollution comes mainly from agricultural production and rural living.

\section{Data Collection}

Landsat Thematic Mapper and Enhanced Thematic Mapper images in 2010 were used to derive thematic landuse maps, including seven categories: forestland, farmland, settlement area, paddy, shrub, grassland, and water area. The research also used 1:50,000 topographic maps of the study area. A total of 325 evenly distributed field-survey points containing land use information were sampled in field surveys. A 1:50,000 digital elevation model (DEM) of the study area was collected from Liaoning surveying and mapping bureau. Slope and aspect maps were derived from the DEM using ARCGIS (Fig. 2).

Data from four years of statistical yearbooks for Liaoning Province and 1:250,000 soil maps derived from the Liaoning soil map were also used. Daily precipitation data monitored by 7 precipitation stations in the watershed were collected from 1998-2012.

The streamflow and sediment record data used to calibrate and validate the utility of the SWAT model were continuous data from January 1976 to December 1981.
Zhangjialouzi $\left(123.51^{\circ} \mathrm{E}, 42.12^{\circ} \mathrm{N}\right)$, the only stream and sediment monitor spot in the watershed, was cancelled after five years of service (1976-81). Data are available from the Chinese Hydrological Yearbook.

\section{Model Calibration and Validation}

Hydrological techniques are often used for modelling watershed hydrology and water quality. ArcSWAT, version 2012 (the graphical user interface for the SWAT model) was used to predict streamflow, sediment transport, and nutrient loss. SWAT is a physically based, continuous time, long-term simulation river basin model that has been widely used to model the hydrology of different hydrological, geological, and climatic conditions on various watershed sizes. Previous studies have already proven that the SWAT model can successfully predict the flow, sediment yield, and nutrient outputs of watersheds located in the immediate vicinity [28].

Sequential Uncertainty Fitting ver. 2 (SUFI-2) integrated into the SWAT Calibration Uncertainty Procedures (SWAT-CUP) platform, was used to perform calibration and validation analysis [29]. In SUFI2, parameter uncertainty accounts for all sources of uncertainties such as uncertainty in driving variables (e.g., rainfall intensity), conceptual model, parameters, and measured data (SWAT-CUP User Manual). Ideal model calibration should consist of three to five years of data that include average, wet, and dry years to emulate significant hydrological events that will trigger model constituent

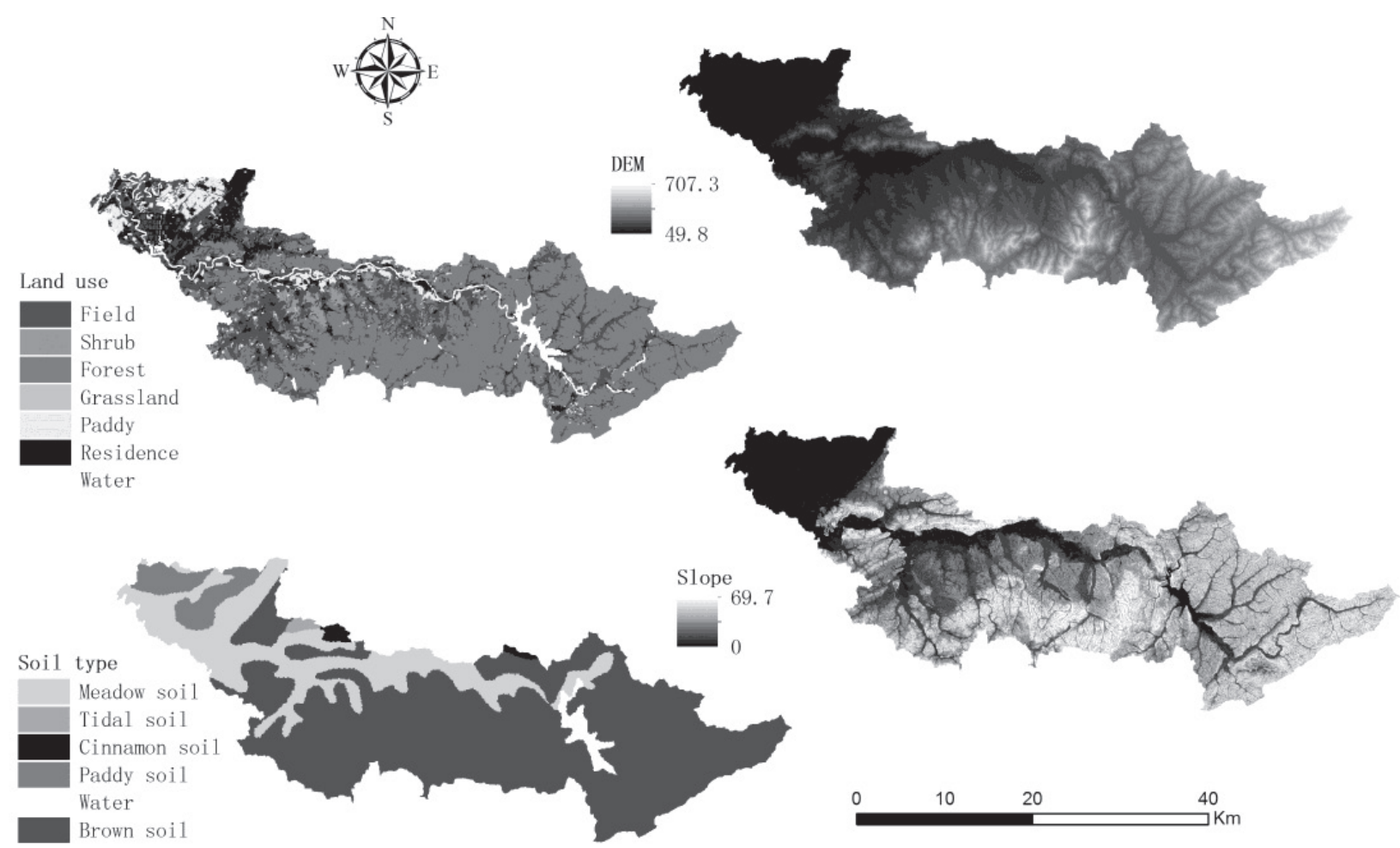

Fig. 2. Land use, digital elevation model, soil, and slope map of the study area; the unit of digital elevation model and slope are meter and degree, respectively. 
processes during calibration. For this study, streamflow and sediment measured data for the warm-up, calibration, and validation periods were 1976, 1977-79, and 1980-81, respectively. The performance of the model was evaluated by coefficient of determination $\left(\mathrm{R}^{2}\right)$ and the Nash-Sutcliffe coefficient (NSE).

\section{Boosted Regression Tree}

Boosted regression tree (BRT) built with $\mathrm{R}$ platform (Team, 2012) was used to quantify the relative importance and marginal effects of environmental influences and their characteristics in affecting NPS loads. The BRT model combines two algorithms: regression tree (the model that relates a response to their predictors by recursive binary splits) and boosting (an adaptive method for combining many simple models to give improved predictive performance) [26].

There are three inter-dependent input settings for the BRT model: the number of trees, learning rate, and tree complexity. The most effective settings were 0.001-0.005 for learning rate and 0.5-0.7 for bag fraction. The learning rate was set to 0.005 , bag fraction to 0.5 , and tree complexity (the number of nodes in a tree) to 5 .

Dependent variables include sediment, TN, and TP. Four independent variables were selected, including elevation, land use, soil, and slope. The Fan watershed was delineated into 53 sub-basins with defining 1,200 hectares to the upstream drainage area, and five gradients (i.e., $\leq 2^{\circ}, 2-6^{\circ}, 6-15^{\circ}, 15-25^{\circ},>25^{\circ}$ ) of slope subdivision based on the rule established by the Ministry of Land and Resources of PRC. The sub-basins were further divided into 1,366 hydrological response units (HRUs) with the default setting, each possessing unique land use/soil attributes/elevation/slope gradient, and NPS yield is predicted separately for each HRU. Accordingly, a data set of 1,366 sites (each corresponded to one HRU) were used for detecting the relationships.

\section{Results and Discussion}

\section{Validation of SWAT Model}

The measured and simulated monthly discharge at the outlet of the Fan watershed is shown in Table $1 . \mathrm{R}^{2}$ coefficient and the Nash-Sutcliffe coefficient (NES) were chosen for accuracy estimation. The $\mathrm{R}^{2}$ coefficient describes the proportion of the variance in measured data explained by the model. $\mathrm{R}^{2}$ ranges between 0 and $1-$ the higher the value the better the fit - and values greater than 0.6 are considered satisfactory [9]. NSE is a normalized statistic that determines the relative magnitude of the residual variance compared to the measured data variance, which ranges from $-\infty$ to 1 , and performance rating is "very good" if values are higher than 0.75 [9, 30-31]. The statistical results indicated a good consistency between the simulated and the observed data both in the calibration and
Table 1. Goodness-of-fit indicator scores between observed and predicted streamflow and sediment for the calibration and validation periods in SWAT modeling.

\begin{tabular}{|c|c|c|c|c|}
\hline \multirow{2}{*}{ Period } & \multicolumn{2}{|c|}{ Streamflow } & \multicolumn{2}{c|}{ Sediment } \\
\cline { 2 - 5 } & $\mathrm{R}^{2}$ & $\mathrm{NSE}$ & $\mathrm{R}^{2}$ & $\mathrm{NSE}$ \\
\hline $\begin{array}{c}\text { Calibration (January 1977 } \\
\text { to December 1979) }\end{array}$ & 0.72 & 0.67 & 0.85 & 0.83 \\
\hline $\begin{array}{c}\text { Validation (January 1980 } \\
\text { to December 1981) }\end{array}$ & 0.82 & 0.82 & 0.93 & 0.89 \\
\hline
\end{tabular}

validation process, with the $\mathrm{R}^{2}$ values higher than 0.76 and NSE higher than 0.67 (Fig. 3).

\section{NPS Pollution}

NPS pollution was estimated from 2003 to 2012. The average yearly load of NPS pollution varies greatly. TN output had the greatest spatial variation with a standard deviation of 26.20, followed by sediment and TP at 9.87 and 7.71, respectively. The largest load values for sediment, TN, and TP were $62.1 \mathrm{t} / \mathrm{ha}, 67.6 \mathrm{~kg} / \mathrm{ha}$, and 35.0 $\mathrm{kg} / \mathrm{ha}$, respectively (Fig. 4).

The mean value of TN output was $19.12 \mathrm{~kg} / \mathrm{ha}$, which was much higher than TP $(3.85 \mathrm{~kg} / \mathrm{ha})$. The spatial pattern of sediment and TP was quite consistent, and Fig. 5 shows the linear fit results of sediments with both TN and TP, and the value of $\mathrm{R}^{2}$ (which amounted to 0.93 , indicating a strong similarity between sediment and TP). The relationship between sediment and TN was weak, and the fitting performance accounted for only $26 \%$.

\section{Relationship of Impact Factors on NPS Pollution}

Relative contribution results in the BRT method displayed in descending order (Fig. 6a). Referring to the
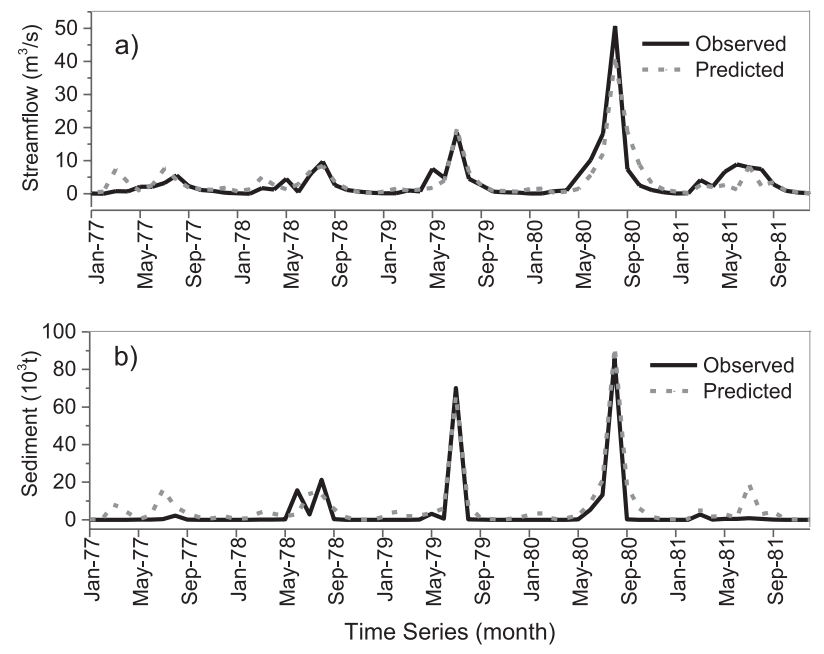

Fig. 3. Time-series of observed and predicted data of monthly streamflow a) and sediment b) during the calibration and validation periods. 


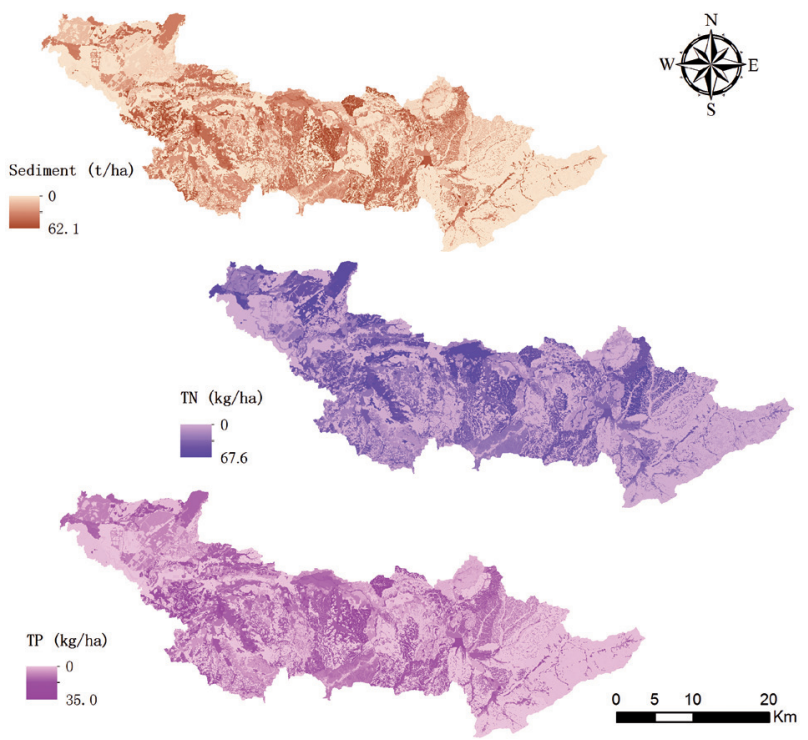

Fig. 4. Spatial distribution of average yearly sediment transport and TN and TP outputs during 2003-12.

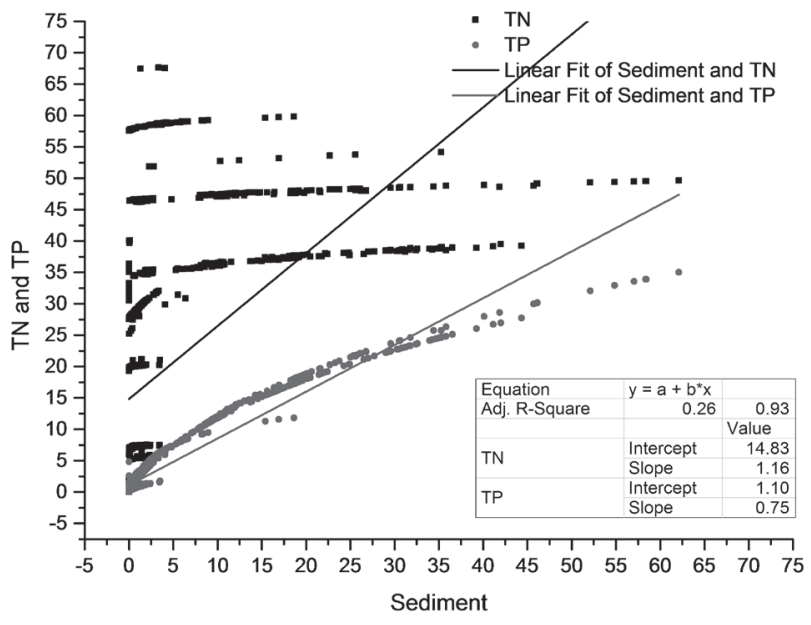

Fig. 5. Linear fit of both sediment with TN and sediment with TP.

information provided, sediment transport had the strongest correlation with slope gradient, which was $46.16 \%$, followed by land use (27.50\%), elevation (19.21\%), and soil type (7.13\%). Partial dependencies from the fitted model indicated that, when other variables were held constant, high sediment output was most likely to be found in places with steep slope, medium gradient with field, and soil type of meadow or cinnamon (Fig. 6).

For the TN load, land use had a proportion of $64.15 \%$, far ahead of elevation, soil type, and slope, with $16.53 \%$, $11.52 \%$, and $7.80 \%$, respectively. Partial dependency plots indicated that agricultural land - including fields and paddies - were far more vulnerable to TN loss than others (Fig. 7b). Cinnamon soil was markedly higher than the meadow soil, which ranked second among all soil types (Fig. 7c); the main trend in relevance increased with increasing slope (Fig. 7d). However, a downward trend was shown following an elevation increase in Fig. $7 \mathrm{e}$.

The contribution percentage of TP in descending order was slope $(38.81 \%)$, land use $(34.52 \%)$, elevation (19.10\%), and soil (7.55\%) (Fig. 8). The partial responses for TP yield of these four variables indicated TP loss most likely occurring in field or paddy land with meadow or cinnamon soil that have steep slope and elevation of about $290 \mathrm{~m}$.

\section{Effectiveness of BRT Model}

This paper combined the SWAT model with the BRT method to investigate the factor complexity of environmental factors on NPS pollutants, including sediment, TN, and TP output. NPS pollution collectively describes the presence of a diverse and complex mixture of environmental factors. The results emphasize that one single pollutant in the study area had different production features closely related to land use, slope, elevation, and soil type in different locations. NPS pollutants are controlled by many factors, and the controlling of one factor may exert a negative effect on another, which made NPS pollution difficult to manage, how to find the best combinations of environmental factors is necessary, more thorough work should be done in a future study. More influencing factors (e.g., precipitation) may be included in the following research.

The study demonstrated the advantages of the BRT model, including no need for variables transformation or merging categories; the explanatory ability to account for nonlinear relationships of several explanatory variables, and to provide satisfactory classification performance with legible quantitative results. Therefore, the BRT method was useful for exploring the relationships between NPS pollution loads and influential factors.

\section{Controls of NPS Pollution Load}

The formation of NPS pollution is a joint effort of natural processes and human activities. Sediment and TP production were more likely related to natural processes, while TN loss was bound up with human activity. NPS pollution can be generated by human activities, and can also be controlled through reasonable arrangement of human activities. Therefore, an attempt to control pollution sources may consider the following strategies:

1) Reducing the amount of anthropogenic $\mathrm{N}$ in the environment.

2) Improving farmland cultivation measures and reducing farmland area on steep slopes.

3) Protective measures should be set in riparian zones.

TN load comes mainly from farmland. Nitrogen is a key limiting nutrient for most crops and many aquatic and terrestrial ecosystems [32]. The massive increase in anthropogenic $\mathrm{N}$ introduced into the environment, largely via $\mathrm{N}$ fertilizers, has had significant negative environmental consequences [33]. Studies showed that a reduction in $\mathrm{N}$ fertilizer application with no loss to yields 
(a)



(d)

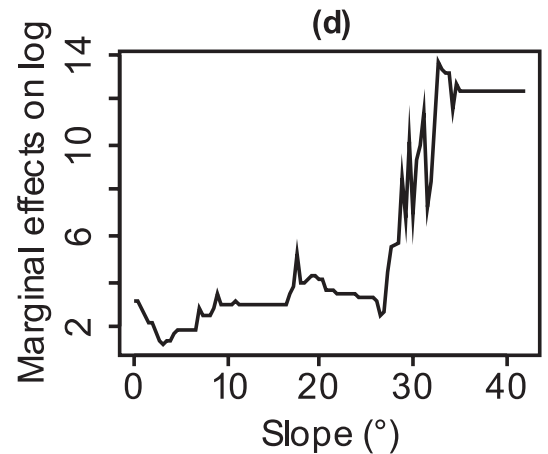

(b)

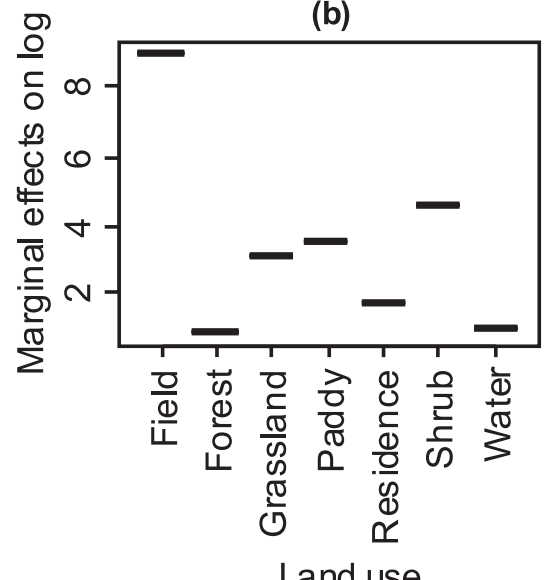

(e)


Fig. 6. Relative influence and partial dependency plots for four variables in the BRT model predicting sediment output.

(a)


Land use

(d)



(e)

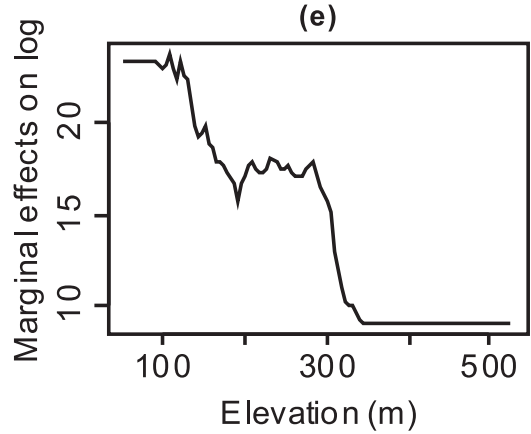

(c)



Fig. 7. Relative influence and partial dependency plots for four variables in the BRT model predicting TN output. 
(a)

\begin{tabular}{|l|}
\hline Slope \\
\hline \hline Land use \\
\hline \hline \multicolumn{2}{|l|}{ Elevation } \\
\hline \hline \multicolumn{2}{|l|}{ Soil } \\
\hline \\
\hline $\begin{array}{ll}10 \quad 20 \quad 30 \\
\text { Relative influence }\end{array}$
\end{tabular}

(d)

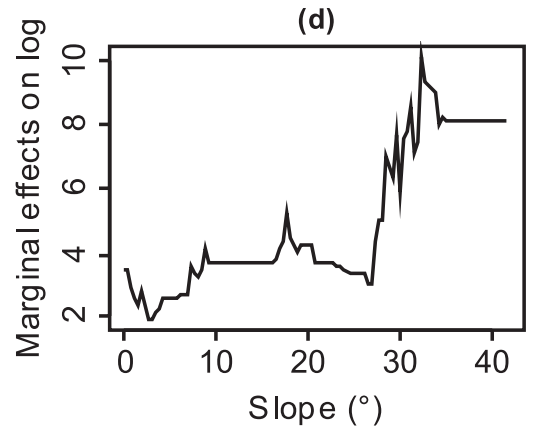

(b)



Land use

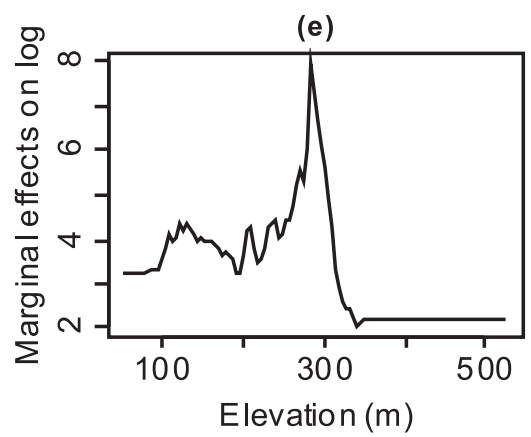

(c)

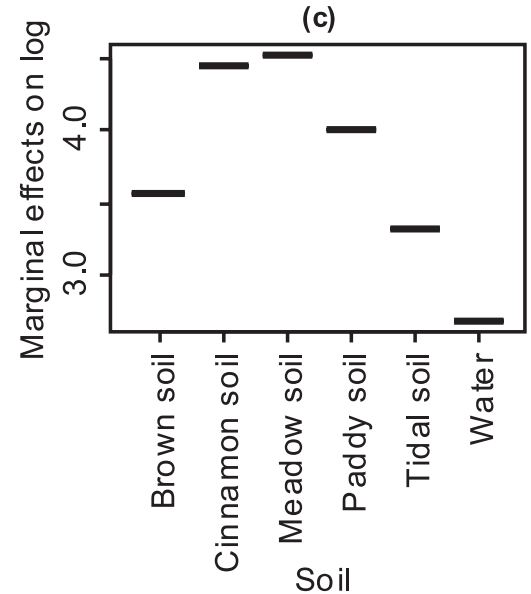

Soil

Fig. 8. Relative influence and partial dependency plots for four variables in the BRT model predicting TP output.

[34], using directed nutrient management strategies, can gain both economic and environmental benefits.

The NPS pollution load varies in different land use types. Cropland with steep slope greatly increase the amount of NPS pollution load with the sediment erosion process. Therefore, reducing farmland area on a steep slope can reduce NPS pollution effectively, especially slope higher than $27^{\circ}$.

Protective measures should be set in riparian zones. Vegetative riparian buffers have been commonly regarded as one of the most effective measures for mitigating the impact of NPS pollution on water quality in rivers [3537], Riparian buffers transform and remove nutrients via a variety of physical, chemical, and biotic processes in the soil and vegetation [10].

\section{Conclusions}

The accuracy of NPS pollution estimation with the SWAT model were estimated with $\mathrm{R}^{2}$ and Nash-Sutcliffe coefficient (NES), which showed that the model is suitable in the study area. The average yearly load of NPS pollution varies greatly from 2003 to 2012 . The spatial pattern of sediment and TP was quite consistent, but the relationship between sediment and TN was weak.

The study combined a SWAT model with the BRT method to investigate the factor complexity of environmental factors on NPS pollutants. Slope has the most important influence on both sediment transport and TP loss. Land use is the leading variable in terms of TN load, the relative influence was nearly three times higher than elevation, which ranked second. Paddy and field are the main source types of TN load, and residential area took third place. Elevation, the second most important impact factor, had a strong negative relationship with TN output in the study area. Soil is the least important factor in sediment transport and TP output.

NPS pollutants are controlled by many factors, and the BRT is an effective method to investigate the factor complexity of environmental factors on NPS pollutants. The study demonstrated the advantages of the BRT model, including no need for variable transformation, the explanatory ability to the nonlinear relationships of variables, and providing satisfactory classification performance with legible quantitative results.

The control strategies of pollution sources were proposed, including reducing anthropogenic $\mathrm{N}$ input, reducing farmland area on a steep slope, and setting protective measures in riparian zones.

NPS pollutants are controlled by many factors that make NPS pollution difficult to manage. How to find the best combination of environmental factors is necessary, and more thorough work should be done in the future.

\section{Acknowledgements}

This project was supported by the National Natural Science Foundation of China (Nos. 41401573, 41671184 and 41501198). 


\section{References}

1. CASON T.N., GANGADHARAN L., DUKE C. A laboratory study of auctions for reducing non-point source pollution. Journal of Environmental Economics and Management. 46 (3), 446, 2003.

2. CHOWDARY V.M., RAO N.H., SARMA P.B.S. Decision support framework for assessment of non-point-source pollution of groundwater in large irrigation projects. Agricultural Water Management. 75 (3), 194, 2005.

3. LIU M., HUANG G.H., LIAO R.F., LI Y.P., XIE Y.L. Fuzzy two-stage non-point source pollution management model for agricultural systems-A case study for the Lake Tai Basin, China. Agricultural Water Management. 121, 27, 2013.

4. ZHANG P., LIU R., BAO Y., WANG J., YU W., SHEN Z. Uncertainty of SWAT model at different DEM resolutions in a large mountainous watershed. Water Research. 53, 132, 2014.

5. GRIFFITH J.A. Geographic techniques and recent applications of remote sensing to landscape-water quality studies. Water Air and Soil Pollution. 138 (1-4), 181, 2002.

6. XIAO H., JI W. Relating landscape characteristics to nonpoint source pollution in mine waste-located watersheds using geospatial techniques. Journal of Environmental Management. 82 (1), 111, 2007.

7. BACIC I.L.Z., ROSSITER D.G., BREGT A.K. Using spatial information to improve collective understanding of shared environmental problems at watershed level. Landscape and Urban Planning. 77 (1-2), 54, 2006.

8. GRAF A., BOGENA H.R., DRUEE C., HARDELAUF H., PUETZ T., HEINEMANN G., VEREECKEN H. Spatiotemporal relations between water budget components and soil water content in a forested tributary catchment. Water Resources Research. 50 (6), 4837, 2014

9. MORIASI D.N., ARNOLD J.G., VAN LIEW M.W., BINGNER R.L., HARMEL R.D., VEITH T.L. Model evaluation guidelines for systematic quantification of accuracy in watershed simulations. Transactions of the Asabe. $\mathbf{5 0}$ (3), 885, 2007.

10. ZHAO P., XIA B., HU Y., YANG Y. A spatial multi-criteria planning scheme for evaluating riparian buffer restoration priorities. Ecological Engineering. 54, 155, 2013.

11. BOLUWADE A., MADRAMOOTOO C. Modeling the Impacts of Spatial Heterogeneity in the Castor Watershed on Runoff, Sediment, and Phosphorus Loss Using SWAT: I. Impacts of Spatial Variability of Soil Properties. Water Air and Soil Pollution. 224 (10), 2013.

12. JOSEPH J.F., GUILLAUME J.H.A. Using a parallelized MCMC algorithm in R to identify appropriate likelihood functions for SWAT. Environmental Modelling \& Software. 46, 292, 2013.

13. SHOPE C.L., MAHARJAN G.R., TENHUNEN J., SEO B., KIM K., RILEY J., ARNHOLD S., KOELLNER T., OK Y. S., PEIFFER S., KIM B., PARK J.H., HUWE B. Using the SWAT model to improve process descriptions and define hydrologic partitioning in South Korea. Hydrology and Earth System Sciences. 18 (2), 539, 2014.

14. BORAH D.K., BERA M. Watershed-scale hydrologic and nonpoint-source pollution models: Review of applications. Transactions of the Asae. 47 (3), 789, 2004.

15. EASTON Z.M., FUKA D.R., WALTER M.T., COWAN D.M., SCHNEIDERMAN E.M., STEENHUIS T.S. Reconceptualizing the soil and water assessment tool (SWAT) model to predict runoff from variable source areas. Journal of Hydrology. 348 (3-4), 279, 2008.
16. SANTHI C., ARNOLD J.G., WILLIAMS J.R., HAUCK L.M., DUGAS W.A. Application of a watershed model to evaluate management effects on point and nonpoint source pollution. Transactions of the Asae. 44 (6), 1559, 2001.

17. CHAHOR Y., CASALI J., GIMENEZ R., BINGNER R.L., CAMPO M.A., GONI M. Evaluation of the AnnAGNPS model for predicting runoff and sediment yield in a small Mediterranean agricultural watershed in Navarre (Spain). Agricultural Water Management. 134, 24, 2014.

18. GAO M., QIU J., LI C., WANG L., LI H., GAO C. Modeling nitrogen loading from a watershed consisting of cropland and livestock farms in China using Manure-DNDC. Agriculture Ecosystems \& Environment. 185, 88, 2014.

19. PARADELO M., SOTO-GOMEZ D., PEREZ-RODRIGUEZ P., POSE-JUAN E., EUGENIO LOPEZ-PERIAGO J. Predicting release and transport of pesticides from a granular formulation during unsaturated diffusion in porous media. Journal of Contaminant Hydrology. 158, 14, 2014.

20. CHANG C.L., LIN Y.T. Using the VIKOR method to evaluate the design of a water quality monitoring network in a watershed. International Journal of Environmental Science and Technology. 11 (2), 303, 2014.

21. KAIGLOVA J., LANGHAMMER J. Analysis of efficiency of pollution reduction measures in rural basin using MIKE Basin model. Case study: Olsava River Basin. Journal of Hydrology and Hydromechanics. 62 (1), 43, 2014.

22. ASLAN A., TRAUTH K.M. Development and Demonstration of a GIS-Based Cumulative Effectiveness Approach to Buffer Design and Evaluation. Journal of Irrigation and Drainage Engineering. 140 (5), 2014.

23. NESHAT A., PRADHAN B., DADRAS M. Groundwater vulnerability assessment using an improved DRASTIC method in GIS. Resources Conservation and Recycling. 86, 74, 2014.

24. PARISIEN M.-A., MORITZ M.A. Environmental controls on the distribution of wildfire at multiple spatial scales. Ecological Monographs. 79 (1), 127, 2009.

25. De'ath G. BOOSTED TREES FOR ECOLOGICAL MODELING AND PREDICTION. Ecology. 88 (1), 243, 2007.

26. ELITH J., LEATHWICK J.R., HASTIE T. A working guide to boosted regression trees. Journal of Animal Ecology. 77 (4), 802, 2008.

27. BROWN D.J., SHEPHERD K.D., WALSH M.G., MAYS M.D., REINSCH T.G. Global soil characterization with VNIR diffuse reflectance spectroscopy. Geoderma. 132 (34), 273, 2006.

28. LIU M., LI C., HU Y., SUN F., XU Y., CHEN T. Combining CLUE-S and SWAT models to forecast land use change and non-point source pollution impact at a watershed scale in Liaoning Province, China. Chinese Geographical Science. 24 (5), 540, 2014

29. ABBASPOUR K.C., YANG J., MAXIMOV I., SIBER R., BOGNER K., MIELEITNER J., ZOBRIST J., SRINIVASAN R. Modelling hydrology and water quality in the pre-ailpine/ alpine Thur watershed using SWAT. Journal of Hydrology. 333 (2-4), 413, 2007.

30. NASH J.E., SUTCLIFFE J.V. River flow forecasting through conceptual models part I - A discussion of principles. Journal of Hydrology. 10 (3), 282, 1970.

31. CASTILLO C.R., GUENERALP I., GUENERALP B. Influence of changes in developed land and precipitation on hydrology of a coastal Texas watershed. Applied Geography. 47, 154, 2014.

32. HAVENS K.E., JAMES R.T., EAST T.L., SMITH V.H. $\mathrm{N}: \mathrm{P}$ ratios, light limitation, and cyanobacterial dominance 
in a subtropical lake impacted by non-point source nutrient pollution. Environmental Pollution. 122 (3), 379, 2003.

33. VITOUSEK P.M., NAYLOR R., CREWS T., DAVID M. B., DRINKWATER L.E., HOLLAND E., JOHNES P.J., KATZENBERGER J., MARTINELLI L.A., MATSON P.A., NZIGUHEBA G., OJIMA D., PALM C.A., ROBERTSON G.P., SANCHEZ P.A., TOWNSEND A.R., ZHANG F.S. Agriculture. Nutrient imbalances in agricultural development. Science. 324 (5934), 1519, 2009.

34. GOOD A.G., BEATTY P.H. Fertilizing Nature: A Tragedy of Excess in the Commons. Plos Biology. 9 (8), 2011.

35. BALESTRINI R., ARESE C., DELCONTE C.A., LOTTI A., SALERNO F. Nitrogen removal in subsurface water by narrow buffer strips in the intensive farming landscape of the
Po River watershed, Italy. Ecological Engineering. 37 (2), 148, 2011.

36. LOWRANCE R., ALTIER L.S., NEWBOLD J.D., SCHNABEL R.R., GROFFMAN P.M., DENVER J.M., CORRELL D.L., GILLIAM J.W., ROBINSON J.L., BRINSFIELD R.B., STAVER K.W., LUCAS W., TODD A.H. Water quality functions of Riparian forest buffers in Chesapeake Bay watersheds. Environmental Management. 21 (5), 687, 1997.

37. WELLER D.E., BAKER M.E., JORDAN T.E. Effects of riparian buffers on nitrate concentrations in watershed discharges: new models and management implications. Ecological Applications. 21 (5), 1679, 2011. 
